\title{
Transformation of the Physical Therapist Assistant (PTA): A Survey of Current Practice and Education
}

Jennifer Jewell

Penn State Shenango, jlj17@psu.edu

Pamela Pologruto

Penn State Fayette, pjp17@psu.edu

Beverly Labosky

Penn State Hazleton, bac34@psu.edu

Gina Tarud

Penn State Hazleton, gmt12@psu.edu

Follow this and additional works at: https://nsuworks.nova.edu/ijahsp

Part of the Physical Therapy Commons

\section{Recommended Citation}

Jewell J, Pologruto P, Labosky B, Tarud G. Transformation of the Physical Therapist Assistant (PTA): A Survey of Current Practice and Education. The Internet Journal of Allied Health Sciences and Practice. 2022 Jan 03;20(1), Article 4.

This Manuscript is brought to you for free and open access by the College of Health Care Sciences at NSUWorks. It has been accepted for inclusion in Internet Journal of Allied Health Sciences and Practice by an authorized editor of NSUWorks. For more information, please contact nsuworks@nova.edu. 


\title{
Transformation of the Physical Therapist Assistant (PTA): A Survey of Current Practice and Education
}

\begin{abstract}
Purpose: To find trends in utilization and practice of the physical therapist assistant (PTA) in the clinical setting and to assess current clinician views on the expected future direction for the education of the PTA. Method/Subjects: An electronic survey was sent to all accredited PT and PTA programs in United States requesting the survey be forwarded to physical therapist and physical therapist assistant faculty, alumni and clinical instructors in their geographic region for completion. Results: PTAs are a vital part of physical therapy practice. Forty percent of respondents reported that greater than $50 \%$ of direct patient interventions are typically delegated to a PTA. Most common interventions not performed by the PTA but is considered a delegable activity include manual techniques and manual muscle testing. Survey results indicated current challenges faced in delivery of healthcare services related to the role of the PTA to be: lack of PTA career development opportunities $(n=615)$, underutilization of the PTA skills/ services $(n=585)$ and productivity standards $(n=545)$. Physical therapist respondents $(72.5 \%)$ reported they completed informal skill training or mentoring with the PTA in the clinic to allow for tasks to be delegated to the PTA. There was consensus among both PT $(52.5 \%, n=399)$ and PTA's $(53.8 \%, n=472)$ that a transition that included a baccalaureate degree was the appropriate career path for the PTA. Conclusions: When coupled with the Federation of State Boards of Physical Therapy (FSBPT) reports of entry level practice expectations, this report could prove valuable in future decision-making regarding PTA degree expectations as well as educational requirements and training to meet the needs of those seeking physical therapy services within our current and future healthcare system.
\end{abstract}

\section{Author Bio(s)}

Jennifer L. Jewell, PT, DPT, GCS, is a Teaching Professor and Academic Coordinator of Clinical Education in the Physical Therapist Assistant Program at Penn State Shenango in Sharon, PA. She is a licensed physical therapist in the state of Pennsylvania and Chair of the Academy of Education Physical Therapist Assistant Educators Special Interest Group.

Pamela J. Pologruto, PT, DPT, is an Associate Teaching Professor and Academic Coordinator of Clinical Education in the Physical Therapist Assistant Program at Penn State Fayette, The Eberly Campus in Lemont Furnace, PA. She is a licensed physical therapist in the state of Pennsylvania and serves as a member of the APTA PA Practice and Research Committee.

Beverly A Labosky, PTA, BA is a licensed physical therapist assistant in the state of Pennsylvania. She is the secretary of the Academy of Education Physical Therapist Assistant Educators Special Interest Group.

Gina Tarud, PT, DPT, is an Associate Teaching Professor in the Physical Therapist Assistant Program at Penn State Hazleton in Hazleton, PA. She is a licensed physical therapist in the state of Pennsylvania.

\section{Acknowledgements}

We thank our colleague, Laura Cruz, PhD from Schreyer Institute for Teaching Excellence at Penn StateUniversity Park, who provided insight and expertise that greatly assisted with this project. 


\title{
IIJAHSP \\ The Internet Journal of Allied Health Sciences and Practice \\ Dedicated to allied health professional practice and education \\ Vol. 20 No. 1 ISSN 1540-580X
}

\section{Transformation of the Physical Therapist Assistant (PTA): A Survey of Current Practice and Education}

\author{
Jennifer Jewell ${ }^{1}$ \\ Pamela Pologruto 2 \\ Beverly Labosky 3 \\ Gina Tarud 3
}

1. Penn State Shenango

2. Penn State Fayette

3. Penn State Hazleton

United States

\begin{abstract}
Purpose: To find trends in utilization and practice of the physical therapist assistant (PTA) in the clinical setting and to assess current clinician views on the expected future direction for the education of the PTA. Methods: An electronic survey was sent to all accredited PT and PTA programs in United States requesting the survey be forwarded to physical therapist and physical therapist assistant faculty, alumni, and clinical instructors in their geographic region for completion. Results: PTAs are a vital part of physical therapy practice. Forty percent of respondents reported that greater than $50 \%$ of direct patient interventions are typically delegated to a PTA. Most common interventions not performed by the PTA but still considered a delegable activity include manual techniques and manual muscle testing. Survey results indicated current challenges faced in delivery of healthcare services related to the role of the PTA to be lack of PTA career development opportunities ( $n=615)$, underutilization of the PTA skills/services $(n=585)$, and productivity standards $(n=545)$. Physical therapist respondents $(72.5 \%)$ reported they completed informal skill training or mentoring with the PTA in the clinic to allow for tasks to be delegated to the PTA. There was consensus among both PTs (52.5\%, $n=399)$ and PTAs $(53.8 \%, n=472)$ that a transition that included a baccalaureate degree was the appropriate career path for the PTA. Conclusions: When coupled with the Federation of State Boards of Physical Therapy (FSBPT) reports of entry level practice expectations, this report could prove valuable in future decision-making regarding PTA degree expectations as well as educational requirements and training to meet the needs of those seeking physical therapy services within our current and future healthcare system.
\end{abstract}

Keywords: PTA, physical therapy, physical therapist assistant education 


\section{INTRODUCTION: THE ROLE OF THE PTA}

The role of the physical therapist assistant (PTA) in the future of delivering physical therapy services is a subject of ongoing, often contested, discussions. These conversations are exacerbated by the lack of specific attention to the role of the PTA in achieving desired patient outcomes within the profession. In 2015, for example, the American Physical Therapy Association (APTA) adopted a three-year strategic plan outlining the future of the profession without explicitly addressing the role of the PTA, aside from the need to develop more educational pathways into the profession. ${ }^{1}$

The most recent APTA strategic plan, adopted in 2019, emphasizes raising quality and consistency standards for both physical therapists (PTs) and PTAs, but provides few strategies for achieving these outcomes outside of the use of a national outcome's registry. ${ }^{2}$ Despite this absence in high-level vision and planning documents for the PTA within the profession, PTA education has made significant strides over the past twenty years. To date, these advances have not resulted in a significant body of evidencebased practice that assesses the large-scale alignment between PTA education and professional practice. The present study seeks to contribute by providing evidence of current PTA professional practice through a literature review and survey of current practice to serve as the basis for developing strategies to bridge the gap between PTA education and professional practice.

The role of the PTA has been debated since its inception in the 1960s. In 2001, the APTA charged the RC-40-01 Task Force to resolve these debates by considering "1) whether or not the scope of work of the PTA should expand, 2) whether or not PTA education level should be raised from the associate degree to the baccalaureate degree level, 3) the feasibility of and need for recognition of enhanced proficiency through post entry-level education and clinical experience, and 4) the prospects for future employment." 3 The task force submitted an interim report in 2002 and afinal report in 2003 to the APTA House of Delegates.,4 The major conclusions of the task force were that 1) "The work of the PTA will be determined by the supervising PT exclusively within the intervention component of the patient/client management model," 2) "An education program culminating in the awarding of an Associate degree is sufficient to prepare the PTA for entry into the workforce," 3 ) "Career development is essential for the PTA and includes clinical experience, continuing education, increased skill proficiency, clinical mentoring, and the recognition thereof," and 4) "while it must be acknowledged that the majority of PTA employment and market factors are not within APTA's control, employment opportunities for the PTA will most likely increase when and where the PT/PTA team is utilized and advocated." 3 This report established a strong baseline of support for the further development of PTA educational pathways, especially the criticality of the two-year associate degree as the basis of professional competency and practice.

Additionally, this report built on the foundations established of the task force by outlining the future/preferred role of the PTA and detailing the PTA entry level curriculum content. ${ }^{3}$ Results of this report indicated general agreement that the PTA educational content should function to prepare the graduate for all facets of work throughout the course of a person's professional career. The report also contained the results of a survey of the membership, which indicated that $58.3 \%$ of PT/PTAs surveyed felt that PTA education was insufficient in clinical problem solving, $61.2 \%$ perceived insufficiency in outcomes measurements, and $67.0 \%$ indicated insufficiency in manual therapy to meet anticipated demands in 2020 workplace. ${ }^{3}$ The report projected changes would need to be made to PTA programs to improve on these desired programmatic and professional outcomes.

The APTA remained largely silent on the matter until a 2012 report detailing the results of a multi-stakeholder feasibility study which explored the possibility of transitioning the entry-level associates degree to a bachelor's degree. ${ }^{5}$ The work group conducted a gap analysis examining differences in content required by CAPTE, National Physical Therapy Examination-PTA content outline, and APTA documents. Although the feasibility study did not result in a change in degree requirements; ongoing substantive changes to the National Physical Therapy Examination-PTA continue to influence/impact PTA education programs to deliver curricular content to prepare students for contemporary practice. ${ }^{5}$

In 2015, the APTA board summarized a plan to address the role and education of the PTA. The recommendations included clarification that APTA polices and positions defining the scope of work of the PTA remain unchanged. The plan included more education about the appropriate utilization of the PTA and the PT-PTA team. Additionally, recommendations included advocacy for the standardization of rules and regulations regarding the PTA across states, though would require changes to state level agreements that are beyond the purview of APTA. PTA entry-level education was to remain as an associate degree with enhanced PTA skills more appropriately addressed in post entry-level education. ${ }^{6}$

While the APTA provides broad leadership to the profession, the FSBPT serves to interpret those principles into a measurable standards of care, entitled Entry Level Work Activity Analysis and Critical Work Activities for the PTA. These standards are reviewed regularly to determine the blueprint for physical therapist assistant licensure/certification. From these standards, educators can make inferences about skill and knowledge requirements to prepare physical therapist assistants for career entry. The 2016 
(FSBPT) Practice Analysis identified 176 critical work activities for entry level PTA practice. This number represents an expansion of the 2007 standards, including the addition of items such as: research and evidence-based practice, performance of spinal and peripheral mobilization (non-thrust), tests, and measures of vestibular function, joint integrity/ROM-spinal joint mobility, and peripheral joint mobility. 7,8 In the past, these skills had been acquired largely through mentorship and continued education. With their inclusion in the 2017 licensure standards, these skills became part of the expectations for entry level clinical practice, and therefore, an appropriate addition to the curriculum of PTA programs.

Since the 2016 FSBPT practice analysis, no national-level studies have assessed the degree to which these expanded categories of entry level PTA work are being utilized in practice; nor have there been studies that assess the extent to which PTA programs may have succeeded in closing the gap between professional preparation and workplace expectations. The purpose of this study is to delineate current trends in utilization and practice of the PTA in the clinical setting and to assess current clinician views on the degree to which PTAs are appropriately trained to serve as integral and effective team members. By taking stock of current practice, the researchers intend to identify actionable education-practice gaps that serve to inform on-going revisions to PTA education programs.

\section{METHODS}

\section{Survey Development}

The researchers developed an electronic survey that focused specifically on the changes to standards, licensure requirements, and expectations delineated in the review of practice summarized above. The survey consisted of 37 items, including 5 demographic questions (including gender, race/ethnicity), 5 professional standing questions (type of clinic, location, years of education, role), and 27 scaled items (including 9-11 questions that were role-specific) related to specific clinical practices that are currently incorporated in the standard PTA curriculum.

Table 1: Demographic Characteristics of Participants

\begin{tabular}{|c|c|c|}
\hline Characteristic & PT & PTA \\
\hline Gender & $\mathrm{N}=811$ & $\mathrm{~N}=904$ \\
\hline Female & $71.0 \%, 576$ & $75.4 \%, 682$ \\
\hline Male & $29.0 \%, 235$ & $24.6 \%, 222$ \\
\hline No response & & \\
\hline APTA Membership & $\mathrm{N}=805$ & $\mathrm{~N}=903$ \\
\hline YES & $53.2 \%, 428$ & $24.1 \%, 218$ \\
\hline $\mathrm{NO}$ & $46.8 \%, 377$ & $75.9 \%, 685$ \\
\hline Highest Degree Earned & $\mathrm{N}=811$ & $\mathrm{~N}=904$ \\
\hline Associate & 0 & $60.6 \%, 548$ \\
\hline Bachelors & $15.8 \%, 128$ & $30.1 \%, 272$ \\
\hline Masters & $27.7 \%, 224$ & $8.1 \%, 73$ \\
\hline Doctorate & $55.1 \%, 447$ & $.1 \%, 1$ \\
\hline Other & $1.5 \%, 12$ & $1.1 \%, 10$ \\
\hline Years of Practice in Field & $\mathrm{N}=809$ & $\mathrm{~N}=905$ \\
\hline$<5$ years & $12.7 \%, 103$ & $37.0 \%, 335$ \\
\hline $5-10$ years & $19.7 \%, 159$ & $21.4 \%, 194$ \\
\hline $10-15$ years & $17.9 \%, 145$ & $9.8 \%, 89$ \\
\hline Greater than 15 years & $49.7 \%, 402$ & $31.7 \%, 287$ \\
\hline $\begin{array}{l}\text { Primary Responsibility (current } \\
\text { position) }\end{array}$ & $\mathrm{N}=810$ & $\mathrm{~N}=905$ \\
\hline Clinical (patient care) & $71.9 \%, 582$ & $89.9 \%, 814$ \\
\hline Administrative (management) & $11.4 \%, 92$ & $5.0 \%, 45$ \\
\hline Academic (educator) & $16.8 \%, 136$ & $5.1 \%, 46$ \\
\hline Practice Setting & $\mathrm{N}=808$ & $\mathrm{~N}=905$ \\
\hline Inpatient rehabilitation & $8.3 \%, 67$ & $8.5 \%, 77$ \\
\hline
\end{tabular}




\begin{tabular}{|r|c|c|}
\hline $\begin{array}{r}\text { Skilled Nursing Care, Extended, or } \\
\text { transitional care facility }\end{array}$ & $7.4 \%, 60$ & $23.2 \%, 210$ \\
\hline Acute Care & $18.1 \%, 146$ & $9.2 \%, 83$ \\
\hline Outpatient & $44.2 \%, 357$ & $44.1 \%, 399$ \\
\hline Home Healthcare & $1.4 \%, 11$ & $6.5 \%, 59$ \\
\hline Hospice & 0 & 0 \\
\hline Floating/Traveling & $.1 \%, 1$ & $.4 \%, 4$ \\
\hline School system & $2.2 \%, 18$ & $1.0 \%, 9$ \\
\hline Military & $.3,2$ & $.1,1$ \\
\hline Academia & $14.8 \%, 119$ & $3.8 \%, 34$ \\
\hline Other & $3.3 \%, 27$ & $3.2 \%, 29$ \\
\hline Geographic Region & $\mathrm{N}=808$ & $\mathrm{~N}=898$ \\
\hline Urban & $34.6 \%, 280$ & $28.7 \%, 258$ \\
\hline Suburban & $44.5 \%, 360$ & $42.3 \%, 380$ \\
\hline Rural & $20.8 \%, 168$ & $28.9 \%, 260$ \\
\hline Geographic Area & $\mathrm{N}=811$ & $\mathrm{~N}=905$ \\
\hline Northeast & $34.9 \%, 283$ & $30.9 \%, 280$ \\
\hline Midwest & $42.9 \%, 348$ & $37.0 \%, 335$ \\
\hline South & $12.7 \%, 103$ & $20.9 \%, 189$ \\
\hline West & $9.5 \%, 77$ & $11.2 \%, 101$ \\
\hline
\end{tabular}

\section{Validity}

The researchers conducted face validity on the survey items through a combination of expert review (a PTA educator with extensive experience in survey development) and focus groups (2 PT/PTA educators). Based on feedback from both sources, questions were adjusted and clarified leading to the development of the final survey. The final survey consisted of 37 questions consisting of multiple choice $(n=17)$, Gutman scale dichotomous format $(n=13)$, and 5 Point Likert scale format $(n=7)$. Contingency questions were used to differentiate PT and PTA professionals. The Pennsylvania State University Office for Research Protections approved the research activity and determined exempt status, allowing the survey to be administered in the summer of 2015.

\section{Dissemination}

The researchers obtained a list of 398 PT and PTA program coordinators from the Commission on Accreditation of Physical Therapy Education (CAPTE) website. Program coordinators were asked to forward the survey link, which was included in the email, to their programs' faculty, clinical instructors, and alumni. Data were collected via Qualtrics from September through October 2015 limiting one response per email address: yielding 1813 raw responses. A formal calculation of response rate is not possible due the method of distribution of the survey, though the overall number of responses is consistent with previous surveys of the field.

\section{RESULTS \\ Demographics}

Out of 1,813 total respondents, 1,683 completed the survey in its entirety, partial responses were recorded for the remaining 130, resulting in fluctuating total responses (ns) per survey item. Percentages were calculated using total responses per question. The respondents were PTAs $(52.7 \%, n=907)$ and PTs $(47.2 \%, n=813)$. The gender differences were wider, with $73.2 \%(n=1,284)$ of the respondents reporting as female, as compared to $26.7 \%(n=468)$ male. This gender differential roughly mirrors known patterns inthe profession ${ }^{9}$. The majority of respondents $(62.1 \%, n=1,084)$ reported not being current APTA members. A typical respondent holds a doctorate in the field if a PT $(55.1 \%, n=447)$, or an associate degree if a PTA (60.6\%, $n=548)$; has 15 years (or more) of experience $(40.0 \%, n=701)$; works in a suburban setting ( $43.3 \%, n=746)$; in the Midwest $(39.7 \%, n=687)$.

In responding to questions about their professional practice, the majority of respondents indicated that their primary responsibilities were clinical (patient care) at $87.8 \%$ ( $n=1518)$, followed by $8.8 \%$ ( $n=184$ ) indicating academia, and $3.3 \%(n=57)$ choosing "other" to describe their role. The majority of respondents reported their primary practice setting as outpatient with $44.2 \%(n=763)$, followed by skilled nursing at $15.6 \%(n=270)$ and academia $(8.9 \%, n=153)$. These patterns, too, are roughly comparable to known patterns 
within the profession, as indicated by periodic surveys commissioned through APTA. 10,11

\section{Role of the PTA}

Three questions on the survey addressed the work of the PTA in relation to the work of the PT. This is a topic of on-going conversations at the national level. Current practice standards recommend that PTs should treat patients at the required care points, including evaluation, re-evaluation, supervisory visit or discharge, and with the option of delegating remaining tasks to the PTA. ${ }^{12}$ In practice, however, $18.5 \%(n=145)$ of physical therapists indicated that they regularly treat patients only at these required care points, while $36.2 \%$ ( $n=287)$ do so occasionally, and $29.9 \%(n=236)$ do not follow this method of clinical practice. Overall, $39.5 \%$ ( $n=249$ ) of PTs indicated that they routinely delegate more than half of all direct patient interventions to their PTA (see Figure 1).

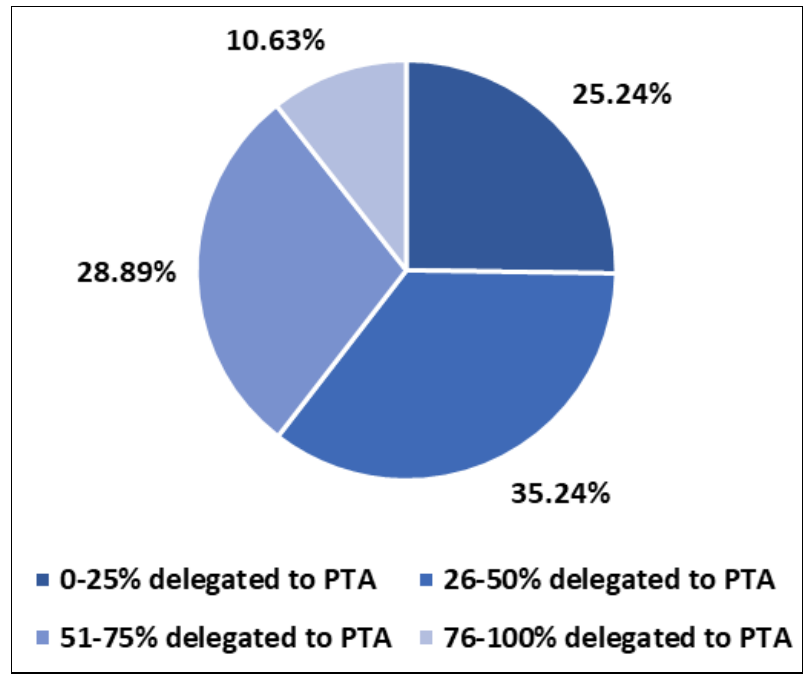

Figure 1. Percentage of direct patient interventions typically delegated to a PTA $(n=630)$

While the previous finding suggests that PTAs may be utilized appropriately, the survey responses also illuminate key areas where they may be under-utilized. Manual techniques and manual muscle testing are both identified delegable by the APTA, but a significant percentage of respondents indicated that these tasks (manual techniques $n=208$, MMT $n=178$ ) were not typically delegated to a PTA. Further, $28.5 \%$ of respondents $(n=787)$ indicated that PTAs in their facility completed delegable interventions with an evaluative component. Open-ended responses indicated that joint mobilizations and sharp debridement were the most common examples of these (see Figure 2).

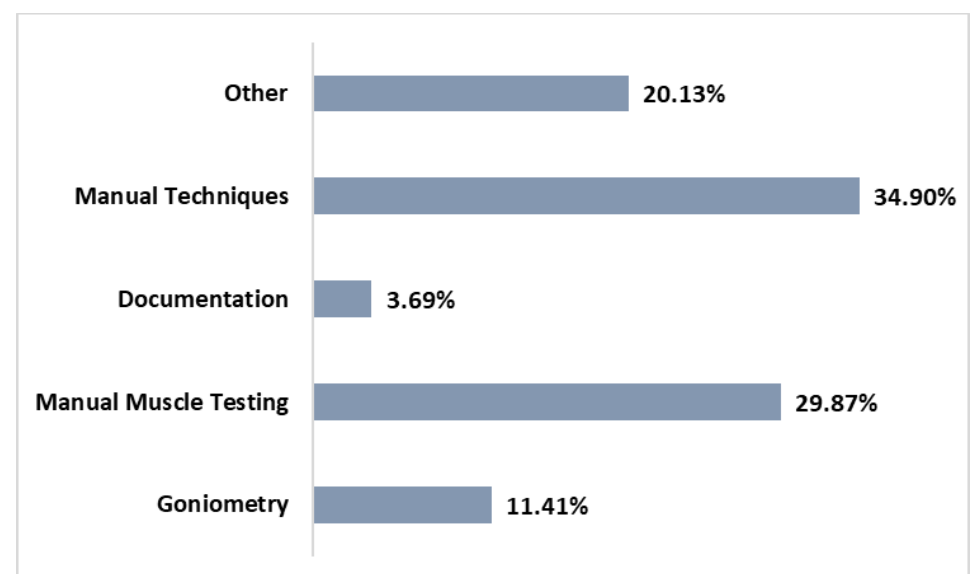

Figure 2: Percentage of interventions/data collection methods not performed by a PTA $(n=596)$. 


\section{Professional Pathways}

The survey results indicated that the vast majority, $96.3 \%$ ( $n=808)$, of responding PTs did not begin their career as PTAs, indicating that the latter role is not currently functioning as a gateway to higher-level careers. Overall, a majority of the respondents indicated that a lack of PTA career-development opportunities was one of the significant challenges associated with the role of the PTA $(n=615)$; followed by underutilization of the PTA skills/services $(n=585)$; regulatory restrictions $(n=488)$, and productivity standards $(n=545)$. (see Figure 3). The majority of respondents indicated that they were not familiar with the APTA's PTA Advanced Proficiency Pathway (APP) $(59.1 \%, n=476)$ or the APTA's Recognition of Advanced Proficiency $(62.3 \%, n=491)$.

Interestingly, while many $(n=585)$ indicated that under-utilization of PTAs is a persistent problem, a group of respondents $(n=153)$ also indicated that over-utilization may also be an issue (eg, "PTA desire to do more than they are trained in"; "PTA practicing beyond their scope and training") suggesting considerable variation in overall practice. A handful of open-ended responses also indicated issues with simply finding qualified PTAs to fill positions (eg, "want more PTAs at our facility, but none available"). Respondents indicated that future job prospects for PTAs in their region were either "good", "very good", or "excellent" (65.9\%, $n=1113)$.

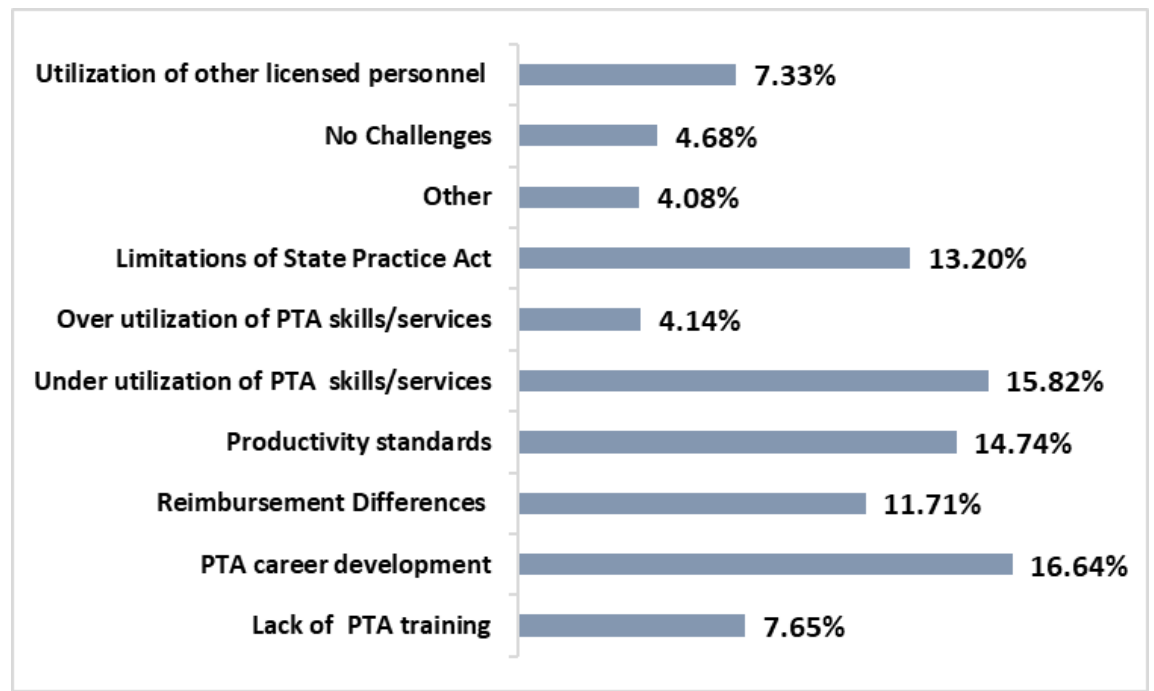

Figure 3. Current challenges in delivery of healthcare related to PTAs

\section{PTA Education}

The majority of PT survey respondents indicated that PTAs do receive informal skill training and/or clinical mentoring $(72.5 \%$, $n=573$ ), but there is also evidence that these efforts are not sufficient to meet the on-going and evolving demands of the modern health care setting. Open-ended responses indicated that PTs perceived that PTAs overall lacked necessary knowledge and/or skills (eg, "lack of confidence in PTA skills") or other desired professional qualities (eg, "new graduates lacking in professional and emotional maturity"). At least one respondent indicated that PTAs also lacked self-efficacy as it relates to continuing education (eg, "want to do more with their license, yet don't want to take the appropriate education"). PTA respondents, on other hand, noted limited access to opportunities for on-going professional development.

These limitations on continuing education in the field suggest that PTA degree programs may need to adjust their curriculum to address these gaps in skills, knowledge, and dispositions. When asked to identify the highest priorities, respondents indicated clinical decision-making skills ( $n=1075)$, progression of PT interventions $(n=1049)$, and documentation $(n=810)$. These finding are consistent with prior studies of gaps in PTA abilities. ${ }^{12}$ In the open-ended category, many respondents commented that PTAs would benefit from increased instruction in specific delegable techniques (eg, manual therapy, joint manipulation). See Figure 4. The proposition of increased educational responsibilities into an already full degree program may provide further support for those in the field who have advocated for a shift from two-year to four-year degree programs for PTAs. Indeed, there was consensus among both PTs $(52.5 \%, n=399)$ and PTAs $(53.8 \%, n=472)$ that a transition that included a baccalaureate degree was the appropriate career path for the PTA. See Figure 5. 


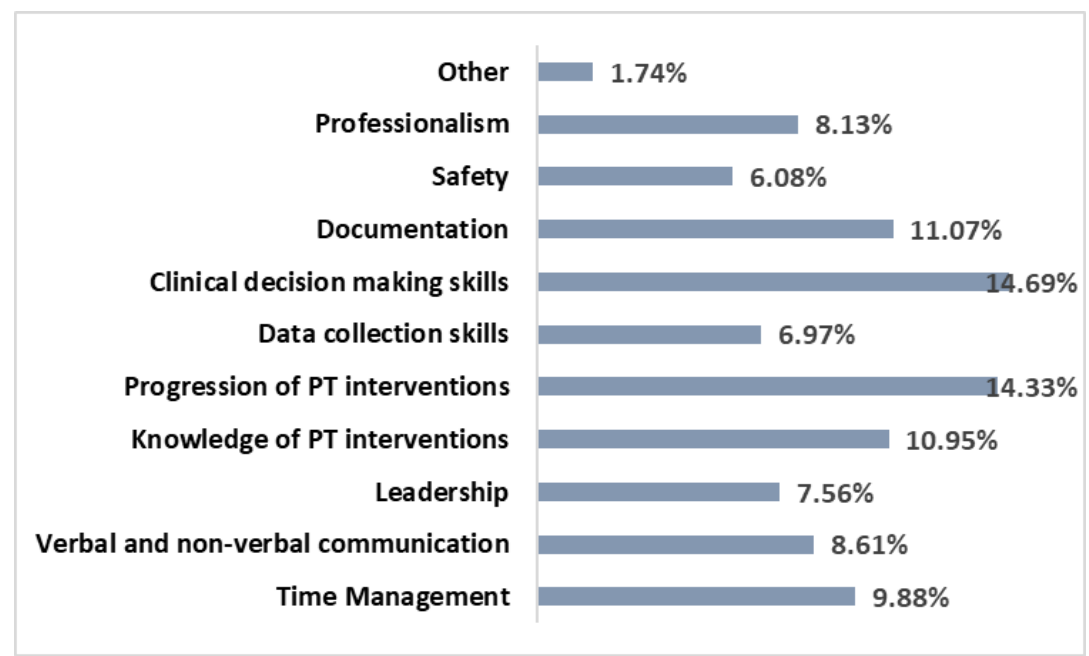

Figure 4. Additional Knowledge/Skills Beneficial in Preparation for PTA

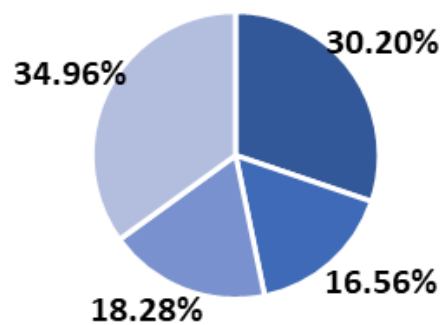

\footnotetext{
- Obta in two year degree and utilize continuing education for advanced skills and ongoing professional development

- Obta in two year degree and utilize advanced proficiency to advance skills in specific treatment area

- Obta in two year degree for entry level and follow up with formal college coursework for bachelors degree in PTA for advanced skills

- Obta in four year degree and utilize continuing education for ongoing professional development
}

Figure 5. Future career path of the PTA

\section{DISCUSSION AND IMPLICATIONS}

The findings of this study affirm that PTAs continue to play a vital role in providing physical therapy services. The majority of respondents who utilized PTAs in their practice reported that greater than $50 \%$ of direct patient interventions are typically delegated to a PTA. Although PTAs are clearly vital components of physical therapy practice, the survey results also indicate that there remains an opportunity for increased clarity, transparency, and consistency in integrating the role of the PTA across multiple clinical settings.

This study suggests several strategies for closing the gaps between research, education, and practice. The findings indicate, for example, that PTAs appear to be underutilized when it comes to specific delegable techniques, especially manual therapy or manual muscle testing. This may be a problem of construct validity within the survey itself, ie, the term manual therapy could include PROM, massage, and joint mobilization; but there is pre-existing corroboration of the perception that PTAs are not sufficiently trained to perform tasks such as manual muscle testing..$^{13}$ The perception persists despite considerable evidence from 
FSBPT practice analysis, indicating that $95.5 \%$ of PTAs successfully performed muscle strength, power, and endurance (MMT) and soft tissue mobilizations at high rates $\left(95.5 \%\right.$ and $91.0 \%$, respectively). ${ }^{8}$ Further research is needed to determine the reason PTAs are not being delegated tasks which are within their scope and knowledge base.

Unlike manual therapy, respondents did report that PTAs are delegated joint mobilizations and sharp debridement; both of which have an evaluative component. This practice stands in contrast to APTA standards which state that PTAs cannot complete interventions that require immediate and continuous examination and evaluation throughout the intervention. Named interventions include spinal and peripheral joint mobilization/manipulation and sharp debridement. ${ }^{14}$ However, not all state practice acts reflect this language, therefore creating discrepancy between the APTA and state practice acts. This discrepancy leads to an ill-defined scope of practice that is questioned by clinicians. Research completed for the RC $40-01$ Task Force reported that $33.1 \%$ of PTs and PTAs strongly disagreed to disagreed with the statement "PTAs should not be involved with those facets of PT services that require examination/evaluation skills simultaneous with intervention."3 Additionally, the FSBPT analysis of practice for the physical therapy profession reported that $56.4 \%$ of PTs/PTAs surveyed completed peripheral/joint mobilizations/manipulations (nonthrust). ${ }^{8}$ Further work is needed to establish consistent practice standards across all states and clinical settings.

The survey results indicate uncertainty remains regarding the extent to which PTAs can be utilized in the provision of physical therapy services in a complex health care system. Indeed, PTA supervision levels vary from state to state and can range from general to direct supervision. While the majority of survey respondents indicated that PTAs receive informal training and mentoring on the job, both PTs and PTAs indicated that these opportunities may not be sufficient to meet continuing education needs for entry-level positions. At the same time, however, respondents emphasized the need for further training in areas that have conventionally been provided through continuing education and mentoring, such as clinical decision making, progression of PT interventions, and documentation. In conjunction with emerging practice areas in the field of physical therapy and the suggestion that most PTA programs currently have maximized their program length (at five semesters-already exceeding the typical timeline for an associate level degree), this suggests the need for changes not just to the content of current PTA courses, but also to the larger current curricular and co-curricular models for PTA education, including re-opening discussions regarding the development of four-year degree programs for optimal efficiency, delegation, and efficacy in the delivery of physical therapy services.

Achieving resolution in PTA education is not a straightforward endeavor, as the curriculum exists in a highly complex environment. A multitude of interdependent factors, ranging from PTA education delivery models, institutional context, reimbursement practice, state practice acts, hiring models, care delivery models, and PTA supervision must be taken into consideration.

\section{CONCLUSIONS}

The present study provides insight into persistent gaps between professional standards, educational models, and clinical practice for PTAs. When coupled with FSBPT reports of entry level practice expectations, this report could prove valuable in future decisionmaking regarding PTA degree expectations and curricular requirements needed to meet the demands of patients seeking physical therapy services within our current and future healthcare system.

Given that there are very limited, published findings related to the clinical utilization of the PTA and PTA educational program efficacy within the context of the rapidly changing healthcare environment, we believe that the findings presented in our paper will appeal to both DPT and PTA educators. Our findings will allow those involved in DPT education to prepare DPT students for appropriate utilization of the PTA within the context of the PT-PTA team while also informing PTA educators of necessary curricular components to prepare graduates for career entry. In doing so, our hope would be for equitable use of the PTA within the clinical setting and to inform appropriate curricular design and length within PTA education. The future of PTA education will require a substantial investment of time, energy, vision, and cooperation within the profession to move forward. More research is required to provide a strong evidence-base to support an updated vision.

\section{REFERENCES}

1. Strategic Plan. American Physical Therapy Association. http://web.archive.org/web/20160602110429/www.apta.org/StrategicPlan/. Updated May 26, 2016. Accessed June 1, 2018.

2. Strategic Plan. American Physical Therapy Association. https://www.apta.org/siteassets/pdfs/apta-strategicplan.pdf. Published May 5, 2020. Accessed February 11, 2021.

3. American Physical Therapy Association. The Future Role of the Physical Therapist Assistant (RC 40-01) Report to 
the 2003 House of Delegates. Contacts: Bohmert JA, Black, JPH. Alexandria, VA.

4. American Physical Therapy Association. The Future Role of the Physical Therapist Assistant (RC 40-01) Report to the 2002 House of Delegates. Contacts: Bohmert JA, Black, JPH. Alexandria, VA.

5. American Physical Therapy Association. RC 20-12 Feasibility Study for Transitioning to an Entry-level Baccalaureate Physical Therapist Assistant Degree. Supplemental Report to 2014 House of Delegates. Board Contact Carolyn Oddo, Staff Contact Janet Crosier. Alexandria, VA.

6. American Physical Therapy Association. Plan to Inform Association Work Related to the Role and Education of the Physical Therapist Assistant and the Use of Other Individuals in the Provision of Physical Therapist Services. February 2015 Professional Affairs Staff Report. Alexandria VA.

7. HumRRO. Analysis of Practice for the Physical Therapy Profession: Entry-Level PhysicalTherapist Assistants. Prepared for FSBPT November 9, 2011; 2011. https://www.fsbpt.org/Portals/O/documents/freeresources/PA2011_PTFinalReport20111109.pdf. Accessed February 14, 2017.

8. HumRRO, Analysis of Practice for the Physical Therapy Profession: Entry-Level Physical TherapistAssistants Final Report. Prepared for FBSPT July 7, 2017; 2016.

https://www.fsbpt.org/Portals/0/documents/freeresources/FinalTechnicalReportPTAFinal20170711.pdf. Accessed February 14, 2017.

9. Raz P, Jensen GM, Walter J, Drake LM. Perspectives on gender and professional issues among female physical therapists. Physical Therapy, 1991;71(7):530-540. doi:1093/ptj/71.7.530

10. Physical Therapist Member Demographic Profile 2016-2017. American Physical Therapy Association. https://www.apta.org/your-career/careers-in-physical-therapy/workforce-data/physical-therapist-demographicprofile. Accessed February 17, 2021.

11. Physical Therapist Assistant Member Demographic Profile 2016-2017. American Physical Therapy Association. https://www.apta.org/your-career/careers-in-physical-therapy/workforce-data/physical-therapist-assistantdemographic-profile. Accessed February 17, 2021.

12. Direction and Supervision of the Physical Therapist Assistant. American Physical Therapy Association. https://www.apta.org/siteassets/pdfs/policies/direction-supervision-pta.pdf. Accessed February 10, 2021.

13. Robinson AJ, McCall M, DePalma MT, et al. Physical therapists' perceptions of the roles of the physical therapist assistant. Physical Therapy. 1994;74(6):571-582. doi:10.1093/pti/74.6.571

14. Interventions Performed Exclusively by Physical Therapists. American Physical Therapy Association. http://www.apta.org/uploadedFiles/APTAorg/About_Us/Policies/Practice/Procedurallnterventions.pdf. Accessed September 25, 2018. 


\section{APPENDIX A: TRANSFORMATION OF THE PHYSICAL THERAPIST ASSISTANT SURVEY}

We are attempting to ascertain information regarding the current role of the physical therapist assistant in healthcare. You are being asked to participate in a research study by volunteering to anonymously complete the brief online survey which will take approximately 10 minutes of your time.

\begin{tabular}{|c|c|c|c|c|c|c|c|}
\hline \multicolumn{2}{|r|}{ Question } & \multicolumn{6}{|c|}{ Responses } \\
\hline 1 & Gender & \multicolumn{2}{|l|}{ Male } & \multicolumn{4}{|c|}{ Female } \\
\hline 2 & $\begin{array}{l}\text { Are you an APTA } \\
\text { member? }\end{array}$ & \multicolumn{2}{|l|}{ Yes } & \multicolumn{4}{|l|}{ No } \\
\hline 3 & $\begin{array}{l}\text { Highest degree } \\
\text { earned }\end{array}$ & Associates & Bachelors & \multicolumn{2}{|c|}{ Masters } & Doctoral & Other \\
\hline 4 & Years of practice & $<5$ years & $5-10$ years & \multicolumn{2}{|c|}{$10-15$ years } & \multicolumn{2}{|l|}{$>15$ years } \\
\hline 5 & $\begin{array}{l}\text { How would you } \\
\text { describe the primary } \\
\text { responsibilities of your } \\
\text { current position? }\end{array}$ & $\begin{array}{l}\text { Clinical } \\
\text { (Patient care) }\end{array}$ & \multicolumn{3}{|c|}{ Administration (Management) } & \multicolumn{2}{|c|}{ Academic (Educator) } \\
\hline \multirow[t]{2}{*}{6} & Practice Setting & Inpatient Rehab & Home Health & Acute & School & Outpatient & Skilled nursing and rehab, extended or transitional care \\
\hline & & Hospice & Military & \multicolumn{2}{|c|}{ Floating/travel } & Academia & \\
\hline 7 & Geographic region & Urban & Suburban & \multicolumn{2}{|l|}{ Rural } & & \\
\hline 8 & $\begin{array}{l}\text { What geographic area } \\
\text { is your primary } \\
\text { workplace located? }\end{array}$ & Northeast & Mid-west & South & & \multicolumn{2}{|l|}{ West } \\
\hline 9 & \multicolumn{2}{|c|}{$\begin{array}{l}\text { What is the average distance from your } \\
\text { primary work location to a Doctorate Level } \\
\text { Physical Therapy program? }\end{array}$} & $<20$ miles & \multicolumn{2}{|c|}{ 20-50 miles } & $50-100$ miles & $>100$ miles \\
\hline 10 & \multicolumn{2}{|c|}{$\begin{array}{l}\text { What is the average distance from your } \\
\text { primary work location to a Physical Therapist } \\
\text { Assistant program? }\end{array}$} & $<20$ miles & \multicolumn{2}{|c|}{ 20-50 miles } & $50-100$ miles & $>100$ miles \\
\hline 11 & $\begin{array}{l}\text { What is your } \\
\text { healthcare profession? }\end{array}$ & \multicolumn{2}{|l|}{ Physical Therapist } & \multicolumn{4}{|c|}{ Physical Therapist Assistant } \\
\hline 22 & $\begin{array}{l}\text { What do you feel are } \\
\text { the current challenges } \\
\text { faced in the delivery of } \\
\text { healthcare related to }\end{array}$ & $\begin{array}{l}\text { Differences in } \\
\text { reimbursement for } \\
\text { PTA provided } \\
\text { services }\end{array}$ & $\begin{array}{l}\text { Utilization of other } \\
\text { licensed personnel } \\
\text { (ie, ATC, Massage }\end{array}$ & $\begin{array}{l}\text { Lack c } \\
\text { for PT } \\
\text { develc }\end{array}$ & $\begin{array}{l}\text { ortunities } \\
\text { eer } \\
\text { tt }\end{array}$ & $\begin{array}{l}\text { Productivity } \\
\text { standards }\end{array}$ & $\begin{array}{l}\text { Inability to delegate PT interventions due to lack of } \\
\text { PTA formal training }\end{array}$ \\
\hline
\end{tabular}

(c) The Internet Journal of Allied Health Sciences and Practice, 2022 


\begin{tabular}{|c|c|c|c|c|c|c|c|c|}
\hline & \multirow[t]{2}{*}{$\begin{array}{l}\text { the role of the PTA? } \\
\text { (Check all that apply) }\end{array}$} & & \multicolumn{2}{|c|}{$\begin{array}{l}\text { Therapist, Exercise } \\
\text { Physiologist) }\end{array}$} & & & & \\
\hline & & $\begin{array}{l}\text { Over utilization of } \\
\text { PTA skills/services }\end{array}$ & \multicolumn{2}{|c|}{$\begin{array}{l}\text { Limitations due to } \\
\text { State Practice Act } \\
\text { regulations }\end{array}$} & \multicolumn{2}{|l|}{ Other } & \multicolumn{2}{|l|}{ No challenges } \\
\hline 23 & $\begin{array}{l}\text { What do you feel the } \\
\text { future career path for } \\
\text { the entry level (new } \\
\text { graduate) PTA should } \\
\text { be? }\end{array}$ & $\begin{array}{l}\text { Obtain two-year } \\
\text { degree and utilize } \\
\text { continuing } \\
\text { education for } \\
\text { advanced skills } \\
\text { and ongoing } \\
\text { professional } \\
\text { development }\end{array}$ & \multicolumn{2}{|c|}{$\begin{array}{l}\text { Obtain two-year } \\
\text { degree and utilize } \\
\text { advanced } \\
\text { proficiency to } \\
\text { advance skills in } \\
\text { specific treatment } \\
\text { area }\end{array}$} & \multicolumn{2}{|c|}{$\begin{array}{l}\text { Obtain two-year } \\
\text { degree for entry level } \\
\text { and follow up with } \\
\text { formal college } \\
\text { coursework for } \\
\text { bachelor's degree in } \\
\text { PTA for advanced } \\
\text { skills }\end{array}$} & \multicolumn{2}{|c|}{$\begin{array}{l}\text { Obtain four-year degree and utilize continuing education for ongoing } \\
\text { professional development }\end{array}$} \\
\hline \multirow[t]{2}{*}{24} & \multirow{2}{*}{$\begin{array}{l}\text { What additional } \\
\text { knowledge or skills do } \\
\text { you feel would be } \\
\text { beneficial in the } \\
\text { academic preparation } \\
\text { of the entry-level } \\
\text { PTA? (Check all that } \\
\text { apply) }\end{array}$} & Time management & \multicolumn{2}{|l|}{$\begin{array}{l}\text { Verbal and Non- } \\
\text { verbal } \\
\text { communication }\end{array}$} & \multicolumn{2}{|c|}{ Leadership } & \multicolumn{2}{|c|}{ Knowledge of PT interventions } \\
\hline & & Safety & \multicolumn{2}{|l|}{ Documentation } & \multicolumn{2}{|c|}{$\begin{array}{l}\text { Clinical decision- } \\
\text { making skills }\end{array}$} & \multicolumn{2}{|l|}{ Professionalism } \\
\hline 25 & \multicolumn{2}{|c|}{$\begin{array}{l}\text { What do you feel the job outlook for PTAs in } \\
\text { your geographic area will be in the future? }\end{array}$} & Poor & Fair & & Good & Very Good & Excellent \\
\hline \multicolumn{9}{|c|}{ Physical Therapist Questions } \\
\hline 12 & $\begin{array}{l}\text { Were you a PTA prior } \\
\text { to becoming a PT? }\end{array}$ & \multicolumn{3}{|l|}{ Yes } & \multicolumn{4}{|c|}{ No } \\
\hline 13 & $\begin{array}{l}\text { How did you obtain } \\
\text { your advanced } \\
\text { professional degree? }\end{array}$ & $\begin{array}{l}\text { Traditional PT } \\
\text { program }\end{array}$ & \multicolumn{2}{|l|}{$\begin{array}{l}\text { Non-traditional } \\
\text { program }\end{array}$} & \multicolumn{2}{|c|}{ Bridge program } & \multicolumn{2}{|l|}{ Other } \\
\hline 14 & \multicolumn{4}{|c|}{$\begin{array}{l}\text { Do you hold an American Board of Physical Therapy Specialty } \\
\text { Certification such as OCS, GCS? }\end{array}$} & \multicolumn{2}{|l|}{ Yes } & \multicolumn{2}{|l|}{ No } \\
\hline 15 & \multicolumn{4}{|c|}{$\begin{array}{l}\text { Are you aware of the APTA PTA Advanced Proficiency Pathways } \\
\text { (APP)? }\end{array}$} & \multicolumn{2}{|l|}{ Yes } & \multicolumn{2}{|l|}{ No } \\
\hline
\end{tabular}




\begin{tabular}{|c|c|c|c|c|c|c|c|c|}
\hline 16 & \multicolumn{2}{|c|}{$\begin{array}{l}\text { As a Physical Therapist, identify your } \\
\text { satisfaction with the following statements: } \\
\text { - } \quad \text { Current employers financial support for } \\
\text { professional development } \\
\text { - } \quad \text { APTA support of the PTA } \\
\text { - } \quad \text { Chapter support of the PTA }\end{array}$} & $\begin{array}{l}\text { Very } \\
\text { Dissatisfied }\end{array}$ & \multicolumn{2}{|c|}{ Dissatisfied } & Satisfied & $\begin{array}{l}\text { Very } \\
\text { Satisfied }\end{array}$ & Unaware of support \\
\hline 17 & \multicolumn{4}{|c|}{$\begin{array}{l}\text { Do you ever complete informal skill training or mentoring with a PTA } \\
\text { in the clinic to allow for tasks to be delegated to the PTA? }\end{array}$} & \multicolumn{2}{|l|}{ Yes } & \multicolumn{2}{|l|}{ No } \\
\hline 18 & \multicolumn{2}{|c|}{$\begin{array}{l}\text { If you delegate care to a PTA, do you ever } \\
\text { ONLY see a patient for the required care } \\
\text { points (eval, re-eval, supervisory visit, and } \\
\text { d/c) with the rest of the treatment being } \\
\text { carried out by the PTA? }\end{array}$} & $\begin{array}{l}\text { Yes - this is } \\
\text { the primary } \\
\text { model }\end{array}$ & \multicolumn{2}{|c|}{$\begin{array}{l}\text { Yes- } \\
\text { occasionally }\end{array}$} & No & \multicolumn{2}{|c|}{ N/A- No PTA's employed } \\
\hline 19 & \multicolumn{2}{|c|}{$\begin{array}{l}\text { Do PTAs in your facility complete } \\
\text { interventions that have evaluative } \\
\text { components traditionally associated with } \\
\text { them? (ex. joint mobilizations, sharp } \\
\text { debridement) }\end{array}$} & \multicolumn{2}{|l|}{ Yes } & \multicolumn{2}{|l|}{ No } & $\begin{array}{l}\text { N/A - } \\
\text { Interventions } \\
\text { not indicated } \\
\text { in my setting }\end{array}$ & N/A - No PTA's employed \\
\hline 20 & $\begin{array}{l}\text { Which of the following } \\
\text { interventions/data } \\
\text { collection methods are } \\
\text { NOT performed by the } \\
\text { PTAs in your facility? } \\
\text { (Check all that apply) }\end{array}$ & Goniometry & \multicolumn{2}{|l|}{$\begin{array}{l}\text { Manual Muscle } \\
\text { Testing }\end{array}$} & \multicolumn{2}{|c|}{ Documentation } & $\begin{array}{l}\text { Manual } \\
\text { Techniques }\end{array}$ & Other \\
\hline 21 & $\begin{array}{l}\text { What percentage of } \\
\text { your direct patient } \\
\text { interventions are } \\
\text { typically delegated to } \\
\text { a PTA? }\end{array}$ & $0-25 \%$ & \multicolumn{2}{|l|}{$26-50 \%$} & \multicolumn{2}{|l|}{$51-75 \%$} & $76-100 \%$ & N/A - No PTA's employed \\
\hline \multicolumn{9}{|c|}{ Physical Therapist Assistant Questions } \\
\hline \multirow[t]{2}{*}{31} & \multirow{2}{*}{$\begin{array}{l}\text { What type of career } \\
\text { development } \\
\text { opportunities have you } \\
\text { participated in? } \\
\text { (Select all that apply) }\end{array}$} & \multirow{2}{*}{$\begin{array}{l}\text { Continuing } \\
\text { education courses } \\
\text { as required for } \\
\text { state } \\
\text { licensure/certificati } \\
\text { on renewal }\end{array}$} & \multirow{2}{*}{\multicolumn{2}{|c|}{$\begin{array}{l}\text { Continuing } \\
\text { education courses } \\
\text { beyond } \\
\text { requirements for } \\
\text { state } \\
\text { licensure/certificatio } \\
\mathrm{n} \text { renewal }\end{array}$}} & \multicolumn{2}{|c|}{$\begin{array}{l}\text { APTA Clinical } \\
\text { Instructor Education } \\
\text { and Credentialing }\end{array}$} & \multirow{2}{*}{$\begin{array}{l}\text { Academic } \\
\text { teaching } \\
\text { (guest } \\
\text { lecturer, lab } \\
\text { instructor, } \\
\text { course } \\
\text { instructor) }\end{array}$} & \multirow[t]{2}{*}{$\begin{array}{l}\text { Clinical teaching (Clinical instructor, Center } \\
\text { Coordinator of Clinical Education) }\end{array}$} \\
\hline & & & & & \multicolumn{2}{|c|}{$\begin{array}{l}\text { State and District level } \\
\text { association } \\
\text { involvement }\end{array}$} & & \\
\hline
\end{tabular}

๑ The Internet Journal of Allied Health Sciences and Practice, 2022 


\begin{tabular}{|c|c|c|c|c|c|}
\hline & & \multicolumn{2}{|c|}{$\begin{array}{l}\text { APTA National level } \\
\text { involvement }\end{array}$} & $\begin{array}{l}\text { APTA Section } \\
\text { level }\end{array}$ & Productivity standards \\
\hline 32 & $\begin{array}{l}\text { As a Physical Therapist Assistant, identify your satisfaction with the } \\
\text { following statements: } \\
\text { - Current employers financial support for professional } \\
\text { - The } \\
\text { - } \quad \text { Your ChentAs support of the PTA } \\
\text { PT's support of the PTA }\end{array}$ & $\begin{array}{l}\text { Very } \\
\text { Satisfied }\end{array}$ & Satisfied & Dissatisfied & Very Dissatisfied \\
\hline 33 & $\begin{array}{l}\text { As a Physical Therapist Assistant, identify your satisfaction with the } \\
\text { following statements: } \\
\text { - Current opportunities available for PTA career development } \\
\text { - Your role as a PTA in the current healthcare environment } \\
\text { - The availability of advanced certification opportunities for the } \\
\text { PTA } \\
\text { - The current continuing education courses available that are } \\
\text { PTA related } \\
\text { - Current academic preparation for the entry-level PTA }\end{array}$ & $\begin{array}{l}\text { Very } \\
\text { Satisfied }\end{array}$ & Satisfied & Dissatisfied & Very Dissatisfied \\
\hline
\end{tabular}

